\title{
Perancangan Sistem Diagnosa Penyakit Saluran Pernapasan Menggunakan Metode Learning Vector Quantization (LVQ)
}

\author{
Zeth Arthur Leleury, Salmon Notje Aulele \\ Jurusan Matematika FMIPA, Universitas Pattimura \\ Jln. Ir. M. Putuhena, Kampus Unpatti, Poka-Ambon
}

Email: zetharthur82@gmail.com, salmon.aulele@yahoo.com

\begin{abstract}
ABSTRAK
Jaringan saraf tiruan telah banyak digunakan untuk membantu menyelesaikan berbagai macam permasalahan dalam rangka pengambilan keputusan berdasarkan pelatihan yang diberikan. Aplikasi jaringan saraf tiruan dapat diterapkan dalam berbagai bidang, salah satunya dalam bidang kesehatan. Learning Vector Quantization (LVQ) adalah salah satu jenis jaringan saraf tiruan yang berbasis pembelajaran kompetitif yang terawasi. Suatu lapisan kompetitif akan secara otomatis belajar untuk mengklasifikasikan vektor-vektor input. Apabila vektor-vektor input memiliki jarak terdekat maka vektor-vektor input tersebut akan dikelompokkan dalam kelas yang sama. Dalam penelitian ini, metode LVQ diaplikasikan untuk mendiagnosa penyakit saluran pernapasan khususnya pada penyakit Tuberculosis, Asma, Sinusitis, Bronchitis, Pneumonia, dan ISPA berdasarkan gejala-gejala dari penyakit saluran pernapasan tersebut. Data yang digunakan dalam penelitian ini sebanyak 109 data, 60 data untuk pelatihan dan 49 data untuk pengujian. Data pada penelitian ini didapat dari ruang rekam medis RSUD Dr. M. Haulussy Ambon. Dari beberapa pengujian menunjukkan bahwa laju pelatihan $(\alpha)=0,1$ dan reduksi laju pelatihan $(\operatorname{Dec} \alpha)=0,00001$ menghasilkan nilai diagnosa terbaik dengan tingkat keakuratan sebesar $95,92 \%$.
\end{abstract}

Kata kunci : Diagnosa, Learning Vector Quantization, Penyakit Saluran Pernapasan

\begin{abstract}
Artificial neural networks have been widely used to help solve various problems in the context of making decision based on the training provided. Application of artificial neural networks can be applied in various fields, one of them in the field of health. Learning Vector Quantization (LVQ) is one type of artificial neural network based supervised competitive learning. The competitive layer will learn automatically to classify the input vector given. If some input vector has the shortest distance then the input vector will be grouped into the same class. In this paper, the LVQ method will be applied to diagnose respiratory diseases particularly in Tuberculosis, Asthma, Sinusitis, Bronchitis, Pneumonia and ISPA based on the symptoms of the respiratory diseases. The data used in this study were 109 data, 60 data for training and 49 data for testing. Data in this study obtained from the medical records space at the Dr. M. Haulussy Hospital Ambon. From some trials showed that the learning rate $(\alpha)=0,1$ and decrease of learning rate $($ Dec $\alpha)=0,00001$ are values that give a good diagnose with level accuracy is about $95,92 \%$.
\end{abstract}

Keywords : Diagnosis, Learning Vector Quantization, The Respiratory Diseases

\section{Pendahuluan}

Seiring dengan perkembangan zaman banyak perubahan teknologi dan informasi yang mengalami kemajuan yang pesat. Peranan komputer sangat penting untuk membantu pekerjaan manusia sehari-hari dalam segala aspek bidang. Pemakai mulanya menggunakan komputer sebagai mesin ketik yang dapat bekerja lebih cepat, tepat, maupun otomatis. Sejalan dengan perkembangan saat ini, para ahli coba menggantikan komputer menjadi suatu alat bantu yang dapat meniru cara kerja otak, sehingga diharapkan suatu saat akan tercipta komputer yang menimbang dan mengambil keputusan sendiri. Hal inilah yang mendorong lahirnya teknologi kecerdasan buatan (Artificial Intelligence). Salah satu teknik komputasi yang dikelompokkan dalam kecerdasan buatan (Artificial Intelligence) adalah Jaringan Saraf Tiruan (Artificial Neural Network). Jaringan saraf tiruan merupakan salah satu sistem pemrosesan yang dirancang dan dilatih untuk memiliki kemampuan seperti yang dimiliki oleh manusia dalam menyelesaikan persoalan yang rumit dengan melakukan proses belajar melalui 
perubahan bobot. Jaringan saraf mensimulasi struktur proses-proses otak (fungsi saraf biologis) dan kemudian membawanya kepada perangkat lunak kelas baru yang dapat mengenali polapola yang kompleks serta belajar dari pengalaman-pengalaman masa lalu. JST merupakan sistem pemrosesan informasi yang mempunyai penampilan karakteristik menyerupai jaringan saraf biologi (Fauset, 1994).

JST adalah salah satu alternatif pemecahan masalah dan banyak diminati oleh para peneliti pada saat ini. Hal ini karena keluwesan yang dimiliki oleh JST, baik dalam perancangan maupun penggunaannya. Penelitian-penelitian tentang aplikasi penggunaan JST melalui pengenalan pola terhadap terjadinya sesuatu telah banyak dikaji dalam berbagai ilmu pengetahuan, diantaranya di bidang kedokteran untuk diagnosa penyakit. Penelitian (Gil, Johnsson, Chamizo, Soriano, \& Ruiz, 2009) menggunakan jaringan saraf tiruan self-organizing map untuk mendiagnosa disfungsi penyakit urologi. Iatrical scholar menggunakan teknik SOM dan teori himpunan untuk menemukan kecenderungan kondisi pasien penderita penyakit kardiovaskular secara individual (Chou etal, 2007).

Selain jaringan SOM, ada juga jaringan saraf tiruan Learning Vector Quantization (LVQ) yang dapat diaplikasikan untuk proses diagnosa. LVQ merupakan salah satu jenis jaringan yang berbasis kompetitif dimana dari nilai keluaran yang diberikan neuron dalam layer keluaran hanya neuron pemenang saja yang diperhatikan. Neuron pemenang tersebut yang akan mengalami pembaruan bobot. LVQ memiliki kelebihan seperti nilai error lebih kecil dibandingkan metode lain serta model yang dihasilkan dapat diperbaharui secara bertahap. Jaringan LVQ berhasil digunakan dalam klasifikasi dari dataset penyakit tiroid untuk memperoleh diagnosa (Temurtas, 2007). Jaringan saraf tiruan dalam mendiagnosa jenis penyakit menyimpan sejumlah data meliputi informasi pada gejala, diagnosis, dan informasi lainnya. Pelatihan jaringan saraf dapat dipresentasikan dengan input yang terdiri dari serangkaian gejala yang diidap oleh penderita. Setelah itu jaringan saraf akan melatih input tersebut sehingga ditemukan suatu akibat dari gejala tersebut yaitu jenis penyakitnya.

Penyakit saluran pernapasan sangat beragam jenis dan gejalanya sehingga seorang dokter perlu mengkaji lebih mendalam gejala yang dialami pasien untuk selanjutnya diputuskan hasil diagnosa penyakit yang diderita pasien. Oleh karena itu dibangun suatu sistem diagnosa. Adapun tujuan penulisan ini adalah merancang suatu program sistem pengambilan keputusan dengan menerapkan jaringan saraf tiruan dengan metode LVQ untuk mendiagnosa jenis penyakit saluran pernapasan berdasarkan gejala-gejala yang dirasakan oleh pasien secara cepat dan tepat sehingga dapat menentukan jenis pengobatan secepatnya. Dalam kasus ini penyakit yang dipilih oleh peneliti adalah penyakit saluran pernapasan guna membantu para dokter untuk menentukan jenis penyakit yang diderita pasien yang datang ke rumah sakit setelah mengarah ke penyakit saluran pernapasan. Diharapkan sistem ini dapat membantu memberikan informasi tentang penyakit saluran pernapasan berdasarkan gejala yang diderita pasien.

\section{Metode Penelitian}

\subsection{Rancangan Penelitian}

Langkah-langkah yang merupakan rancangan penelitian ini terdiri dari 4 tahapan antara lain:

a. Pengumpulan data

Data yang dikumpulkan adalah hasil rekam medis pasien penderita penyakit saluran pernapasan (tuberculosis, asma, sinusitis, bronchitis, pneumonia, dan ISPA) yakni data gejala-gejala yang dialami oleh setiap pasien dan jenis penyakit yang diderita berdasarkan diagnosa dokter. Data yang akan digunakan berupa data sekunder yang diperoleh dari data rekam medis setiap pasien penderita saluran pernapasan di Rumah Sakit Dr. M. Haulussy Ambon. Data tersebut selanjutnya akan digunakan untuk melakukan pelatihan program dan sebagai data latih serta data uji untuk sistem.

b. Merancang dan membuat sistem diagnosa dengan menggunakan software Matlab.

Setelah data terkait gejala-gejala setiap penyakit saluran pernapasan diperoleh, langkah selanjutnya adalah merancang sistem diagnosa untuk mengenali gejala-gejala penyakit saluran pernapasan yang ada. Dalam pembuatan sistem, tahap yang dilakukan mulai dari pembuatan desain program dengan menggunakan Grapics User Interface (GUI) kemudian dilanjutkan dengan membuat coding Matlab agar desain program dapat berfungsi. 
c. Melakukan pengujian sistem

Pada tahap ini dilakukan pengujian terhadap sistem yang telah dirancang. Pengujian sistem dilakukan dengan menghitung tingkat akurasi sistem dalam mendiagnosa jenis penyakit pada data testing.

d. Penarikan kesimpulan

Penarikan kesimpulan didasarkan pada hasil analisis dari penelitian yakni tingkat akurasi sistem yang dihasilkan pada proses mendiagnosa jenis penyakit saluran pernapasan.

\subsection{Teknik Analisa Data}

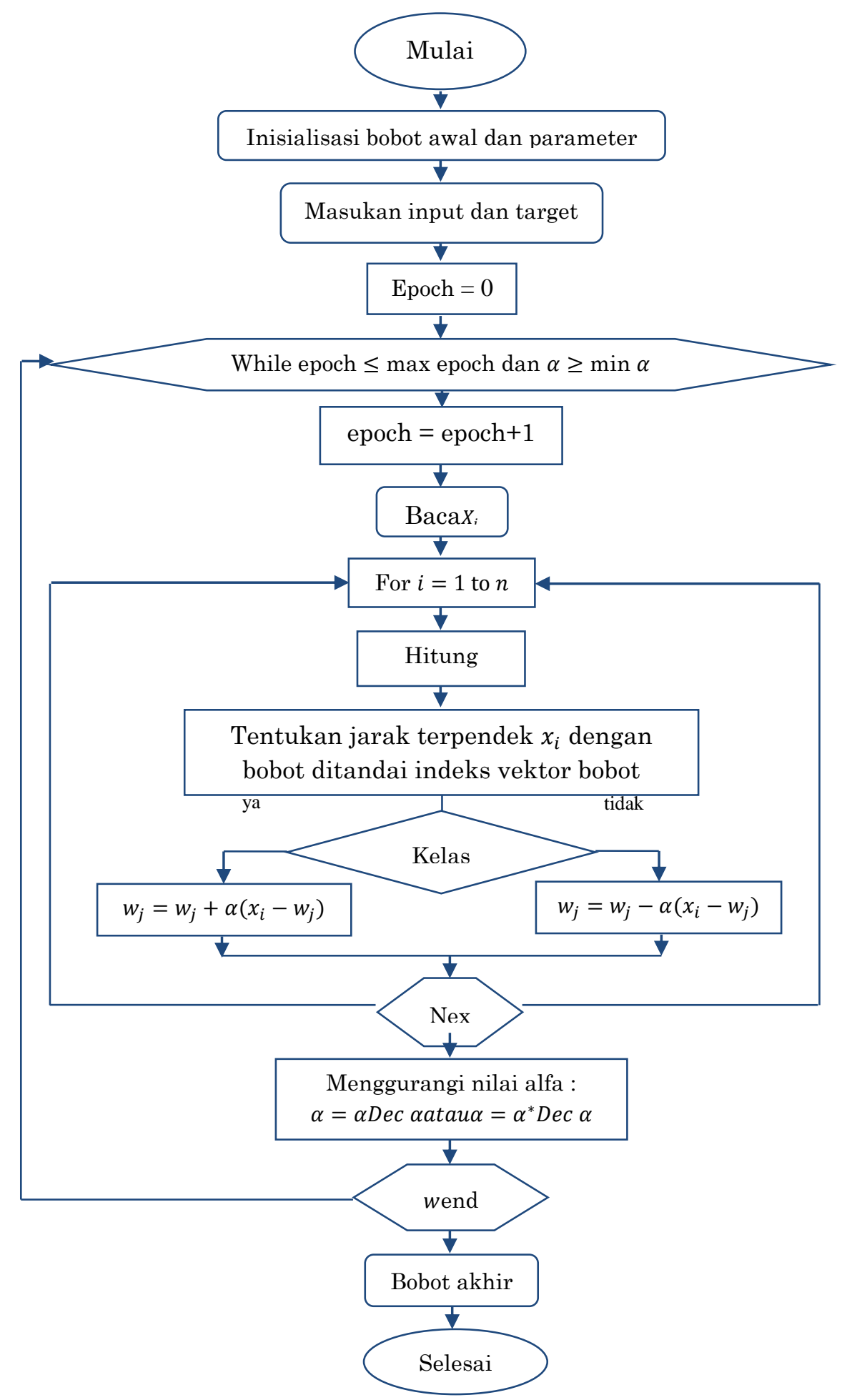

Gambar.1 Diagram Alir Proses Training pada Jaringan LVQ 
Teknik analisis data dalam penelitian ini dapat didasarkan pada algoritma proses pembelajaran pada metode LVQ yang dapat disajikan pada Gambar 1 di atas. Setelah dilakukan pelatihan maka akan diperoleh bobot-bobot akhir. Bobot ini selanjutnya akan digunakan untuk melakukan testing atau pengujian. Algoritma proses pengujian disajikan dalam Gambar 2 berikut.

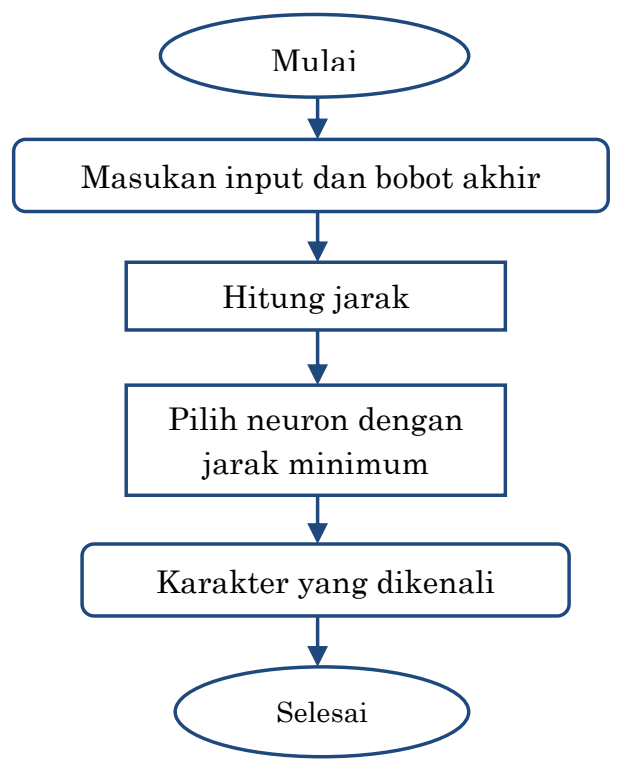

Gambar.2 Diagram Alir Proses Testing pada Jaringan LVQ

\section{Hasil dan Pembahasan}

\subsection{Penetapan Variabel Input}

Input yang digunakan di dalam aplikasi ini adalah berupa gejala-gejala penyebab penyakit saluran pernapasan. Dimana gejala-gejala yang digunakan untuk mendiagnosa penyakit saluran pernapasan didasarkan pada sumber data pasien yang diperoleh. Berdasarkan gejala klinisnya, penyakit saluran pernapasan yaitu Tuberculosis, Asma, Sinusitis, Bronchitis, Pneumonia, dan ISPA memiliki 16 gejala yang selanjutnya menjadi variabel input pada jaringan saraf tiruan. Gejala-gejala tersebut adalah batuk, sesak nafas, nyeri dada, mual dan muntah, demam, nyeri kepala, nyeri ulu hati, menggigil, berkeringat dingin, susah tidur, pilek, keluar secret/ingus, mudah lelah, kekakuan sendi, lidah berjamur dan hidung tersumbat. Gejala-gejala penyakit saluran pernapasan tersebut ditentukan, selanjutnya adalah menentukan nilai dari masing-masing gejala. Nilai terhadap variabel ditentukan antara 0 sampai dengan 1, disesuaikan dengan kasus dari masing-masing gejala. Pada penelitian ini, ditetapkan jika semakin tinggi nilai dari variabel tersebut maka penyakit yang diderita semakin parah, dan sebaliknya semakin rendah nilai suatu variabel maka penyakit yang diderita semakin ringan. Adapun variabel dan nilai dari masing-masing gejala penyakit disajikan pada Tabel 1.

\subsection{Penetapan Variabel Output}

Selanjutnya output yang akan diperoleh adalah penyakit saluran pernapasan yaitu, tuberculosis, asma, sinusitis, bronchitis, pneumonia dan ISPA. Rancangan penetapan keluaran (output) sebagai berikut:

1. Diberi nilai "1" untuk pasien yang didiagnosa penyakit tuberculosis.

2. Diberi nilai "2" untuk pasien yang didiagnosa penyakit asma.

3. Diberi nilai "3" untuk pasien yang didiagnosa penyakit sinusitis.

4. Diberi nilai "4" untuk pasien yang didiagnosa penyakit bronchitis.

5. Diberi nilai "5" untuk pasien yang didiagnosa penyakit pneumonia.

6. Diberi nilai "6" untuk pasien yang didiagnosa penyakit ISPA. 
Tabel 1. Gejala-Gejala Penyakit dan Nilainya

\begin{tabular}{|c|c|c|}
\hline Gejala-gejala & Variabel & Nilai \\
\hline \multirow{4}{*}{ Batuk $\left(X_{1}\right)$} & Tidak & 0 \\
\hline & Kering & 0.25 \\
\hline & Berdahak & 0.5 \\
\hline & Berdahak berdarah & 1 \\
\hline \multirow{3}{*}{ Sesak Nafas $\left(X_{2}\right)$} & Tidak & 0 \\
\hline & Jarang terjadi & 0.5 \\
\hline & Terus menerus & 1 \\
\hline \multirow{3}{*}{ Nyeri Dada $\left(X_{3}\right)$} & Tidak & 0 \\
\hline & Jarang terjadi & 0.5 \\
\hline & Sering Terjadi & 1 \\
\hline \multirow{4}{*}{ Mual dan Muntah $\left(X_{4}\right)$} & Tidak & 0 \\
\hline & Mual & 0.25 \\
\hline & Muntah & 0.5 \\
\hline & Mual dan muntah & 1 \\
\hline \multirow[t]{3}{*}{$\operatorname{Demam}\left(X_{5}\right)$} & Tidak & 0 \\
\hline & Jarang terjadi & 0.5 \\
\hline & Sering Terjadi & 1 \\
\hline \multirow{2}{*}{ Nyeri Kepala $\left(X_{6}\right)$} & Tidak & 0 \\
\hline & $\mathrm{Ya}$ & 1 \\
\hline \multirow[b]{2}{*}{ Nyeri Ulu Hati $\left(X_{7}\right)$} & Tidak & 0 \\
\hline & $\mathrm{Ya}$ & 1 \\
\hline \multirow{2}{*}{ Menggigil $\left(X_{8}\right)$} & Tidak & 0 \\
\hline & $\mathrm{Ya}$ & 1 \\
\hline \multirow{3}{*}{ Berkeringat Dingin $\left(X_{9}\right)$} & Tidak & 0 \\
\hline & Sering & 0.5 \\
\hline & Sering pada malam hari & 1 \\
\hline \multirow{2}{*}{ Susah Tidur $\left(X_{10}\right)$} & Tidak & 0 \\
\hline & $\mathrm{Ya}$ & 1 \\
\hline \multirow{2}{*}{ Pilek $\left(X_{11}\right)$} & Tidak & 0 \\
\hline & $\mathrm{Ya}$ & 1 \\
\hline \multirow{3}{*}{ Keluar Sekret/ingus $\left(X_{12}\right)$} & Tidak & 0 \\
\hline & $\mathrm{Ya}$ & 0.5 \\
\hline & Ya dan berbau & 1 \\
\hline \multirow{2}{*}{ Mudah Lelah $\left(X_{13}\right)$} & Tidak & 0 \\
\hline & $\mathrm{Ya}$ & 1 \\
\hline \multirow{2}{*}{ Kekakuan Sendi $\left(X_{14}\right)$} & Tidak & 0 \\
\hline & $\mathrm{Ya}$ & 1 \\
\hline \multirow{2}{*}{ Lidah Berjamur $\left(X_{15}\right)$} & Tidak & 0 \\
\hline & $\mathrm{Ya}$ & 1 \\
\hline \multirow{3}{*}{ Nyeri pada Hidung $\left(X_{16}\right)$} & Tidak & 0 \\
\hline & $\mathrm{Ya}$ & 0.5 \\
\hline & Ya dan terasa nyeri & 1 \\
\hline
\end{tabular}




\subsection{Perancangan Pengolahan Data}

Adapun jumlah data dari penyakit saluran pernapasan yang diperoleh sebanyak 109 buah data, dimana 54 data digunakan untuk pelatihan, 6 data sebagai bobot awal dan 49 data untuk pengujian keakuratan sistem yang digunakan untuk mengenali pola masukan.

Tabel 2 Jarak Antara Data Testing dengan Bobot Output Hasil Training

\begin{tabular}{|c|c|c|c|c|c|c|c|c|c|c|c|c|c|c|c|c|c|}
\hline \multirow{2}{*}{$\begin{array}{l}0 \\
0 \\
0.0 \\
0 \\
0 \\
0\end{array}$} & \multicolumn{6}{|c|}{ Kluster } & \multirow{2}{*}{ 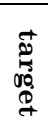 } & \multirow{2}{*}{$\begin{array}{l}\text { S. } \\
\stackrel{0}{0} \\
\stackrel{0}{=}\end{array}$} & \multirow{2}{*}{ 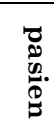 } & \multicolumn{6}{|c|}{ Kluster } & \multirow{2}{*}{ 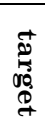 } & \multirow[b]{2}{*}{ 气. } \\
\hline & 1 & 2 & 3 & 4 & 5 & 6 & & & & 1 & 2 & 3 & 4 & 5 & 6 & & \\
\hline 1 & 1.07 & 2.25 & 2.29 & 1.92 & 2.39 & 2.01 & 1 & 1 & 26 & 1.85 & 1.81 & 2.69 & 2.55 & 1.82 & 2.46 & 2 & 2 \\
\hline 2 & 1.32 & 2.34 & 2.69 & 1.78 & 2.15 & 2.42 & 1 & 1 & 27 & 1.98 & 1.75 & 2.51 & 2.73 & 2.02 & 2.34 & 2 & 2 \\
\hline 3 & 1.50 & 2.13 & 2.07 & 1.58 & 2.32 & 1.90 & 1 & 1 & 28 & 1.89 & 1.76 & 2.45 & 2.69 & 1.92 & 2.40 & 2 & 2 \\
\hline 4 & 1.38 & 2.13 & 2.00 & 1.50 & 2.23 & 1.96 & 1 & 1 & 29 & 2.24 & 1.63 & 2.69 & 2.09 & 1.94 & 2.81 & 2 & 2 \\
\hline 5 & 1.52 & 1.87 & 2.74 & 1.90 & 1.61 & 2.23 & 1 & 1 & 30 & 1.64 & 1.49 & 2.35 & 2.35 & 1.62 & 2.30 & 2 & 2 \\
\hline 6 & 1.38 & 2.13 & 2.70 & 2.50 & 2.32 & 2.12 & 1 & 1 & 31 & 1.98 & 1.75 & 2.51 & 2.73 & 2.02 & 2.34 & 2 & 2 \\
\hline 7 & 1.00 & 2.21 & 2.18 & 1.31 & 2.19 & 1.54 & 1 & 1 & 32 & 2.39 & 1.75 & 2.36 & 2.47 & 2.55 & 1.94 & 2 & 2 \\
\hline 8 & 1.27 & 1.84 & 2.40 & 1.71 & 1.84 & 1.83 & 1 & 1 & 33 & 2.02 & 1.75 & 2.56 & 2.57 & 1.81 & 2.18 & 2 & 2 \\
\hline 9 & 1.52 & 1.87 & 2.74 & 1.90 & 1.61 & 2.23 & 1 & 1 & 34 & 1.64 & 1.49 & 2.35 & 2.35 & 1.62 & 2.30 & 2 & 2 \\
\hline 10 & 1.45 & 2.34 & 2.75 & 1.84 & 2.24 & 2.36 & 1 & 1 & 35 & 1.96 & 1.72 & 2.75 & 2.28 & 2.26 & 2.15 & 2 & 2 \\
\hline 11 & 1.07 & 2.25 & 2.29 & 1.92 & 2.39 & 2.01 & 1 & 1 & 36 & 2.13 & 1.76 & 2.31 & 2.75 & 2.12 & 2.08 & 2 & 2 \\
\hline 12 & 1.51 & 2.13 & 2.07 & 1.58 & 2.32 & 1.90 & 1 & 1 & 37 & 1.98 & 1.72 & 2.76 & 2.30 & 2.34 & 2.23 & 2 & 2 \\
\hline 13 & 1.32 & 2.34 & 2.69 & 1.78 & 2.15 & 2.42 & 1 & 1 & 38 & 2.61 & 2.80 & 0.05 & 2.54 & 3.06 & 2.42 & 3 & 3 \\
\hline 14 & 1.24 & 2.06 & 2.06 & 1.63 & 1.75 & 2.17 & 1 & 1 & 39 & 1.52 & 2.39 & 2.55 & 1.49 & 1.95 & 2.12 & 4 & 4 \\
\hline 15 & 1.47 & 2.23 & 2.51 & 2.22 & 2.37 & 1.85 & 1 & 1 & 40 & 1.86 & 2.14 & 2.50 & 1.80 & 2.06 & 2.41 & 4 & 4 \\
\hline 16 & 1.45 & 2.34 & 2.75 & 1.84 & 2.24 & 2.36 & 1 & 1 & 41 & 1.00 & 2.20 & 2.18 & 1.31 & 2.19 & 1.53 & 4 & 1 \\
\hline 17 & 1.24 & 2.15 & 2.55 & 2.20 & 2.05 & 1.91 & 1 & 1 & 42 & 1.86 & 2.14 & 2.50 & 1.80 & 2.06 & 2.41 & 4 & 4 \\
\hline 18 & 1.46 & 2.41 & 2.65 & 1.66 & 2.20 & 2.57 & 1 & 1 & 43 & 2.29 & 2.06 & 2.87 & 2.02 & 2.01 & 2.29 & 5 & 5 \\
\hline 19 & 1.14 & 2.37 & 2.34 & 2.41 & 1.98 & 2.19 & 1 & 1 & 44 & 2.14 & 2.55 & 2.87 & 2.02 & 2.01 & 2.29 & 5 & 5 \\
\hline 20 & 1.38 & 2.20 & 2.70 & 2.50 & 2.37 & 1.52 & 1 & 1 & 45 & 1.99 & 1.44 & 2.78 & 2.30 & 0.41 & 2.43 & 5 & 5 \\
\hline 21 & 1.16 & 2.16 & 2.61 & 2.36 & 2.34 & 1.99 & 1 & 1 & 46 & 2.50 & 2.86 & 3.07 & 2.75 & 2.35 & 2.15 & 6 & 6 \\
\hline 22 & 2.28 & 2.02 & 2.70 & 2.98 & 2.26 & 2.55 & 2 & 2 & 47 & 2.10 & 2.68 & 2.69 & 2.87 & 2.64 & 1.44 & 6 & 6 \\
\hline 23 & 1.99 & 2.12 & 2.70 & 1.75 & 2.51 & 2.08 & 2 & 4 & 48 & 1.87 & 2.59 & 2.36 & 2.46 & 2.72 & 0.18 & 6 & 6 \\
\hline 24 & 2.49 & 1.93 & 2.55 & 2.37 & 2.30 & 2.46 & 2 & 2 & 49 & 2.26 & 2.88 & 2.92 & 2.56 & 2.70 & 1.62 & 6 & 6 \\
\hline
\end{tabular}

Pada metode Learning Vector Quantization, bobot awal menggunakan pola-pola yang sudah ada. Kemudian bobot tersebut akan diubah (di-update) tergantung dari kelas vektor masukan sesuai dengan kelas yang dinyatakan sebagai neuron pemenang. Bobot awal diambil dari data yang sudah ada yang harus dibawa ke dalam bentuk vektor. Vektor bobot ini dituliskan dengan $\left(w_{1 j}=w_{11}, w_{12}, w_{13}, \ldots, w_{1 m}\right)$ yang merupakan vektor bobot kelas pertama dengan $m$ variabel dan selanjutnya sampai kelas terakhir. Pada penelitian ini, data terbagi dalam 6 kelas dengan 16 variabel. Karena harus dalam bentuk vektor, maka bentuk bobot awal yang mewakili 6 bobot dari enam jenis penyakit saluran pernapasan adalah sebagai berikut:

$$
\begin{aligned}
& w_{1 j}=(0.5,1,0.5,0.5,0.5,1,0,0,1,0,0,0,0,0,0,0) \\
& w_{2 j}=(0.5,0.5,0.5,0,0,0,1,0,0,1,0,0,0,1,0,0) \\
& w_{3 j}=(0.5,0.5,0,0,0,1,0,0,0,0,1,1,0,0,1,1) \\
& w_{4 j}=(0.5,0.5,0,1,0,1,0,0,0,0,0,0,0,0,0,0) \\
& w_{5 j}=(1,0.5,0.5,0.5,0,0,0,0,0,1,0,0,0,1,0,0)
\end{aligned}
$$




$$
w_{6 j}=(1,1,1,0,1,1,0,0,0,0,1,0,0,0,0,0)
$$

Parameter-parameter yang digunakan dalam penelitian ini adalah sebagai berikut:

1. Laju pelatihan, $\alpha=0,1$

2. Penurunan laju pelatihan, Dec $\alpha=0,00001$

3. Maksimum epoch, Max Epoch $=10$

Setelah diperoleh bobot akhir hasil pelatihan data training, selanjutnya bobot output hasil training digunakan pada tahap testing dengan input data yang baru. Pada tahap testing ini, akan di hitung jarak vektor antara data testing dan bobot akhir, dengan menggunakan jarak Euclidean. Selanjutnya ditentukan klaster data dengan memilih jarak vektor yang minimum sebagai pemenang.

Berdasarkan Tabel 2, terlihat bahwa setelah dilakukan testing dengan menghitung jarak Euclidean dan memilih jarak minimum sebagai neuron pemenang maka diperoleh bahwa dari 49 data testing diperoleh hasil yaitu 47 pasien memiliki karakter yang dapat dikenali atau diagnosa dengan menggunakan program sama dengan hasil diagnosa dari dokter dan 2 pasien (pasien ke-23 dan ke-41) yang tidak sesuai. Pasien ke-23 memiliki diagnosa penyakit Asma, namun setelah dilakukan proses diagnosa menggunakan program, pasien tersebut didiagnosa memiliki penyakit Bronchitis. Sedangkan pasien ke-41 memiliki diagnosa penyakit Bronchitis, namun setelah dilakukan proses diagnosa menggunakan program, pasien tersebut didiagnosa memiliki penyakit Tuberculosis. Hal ini disebabkan karena gejala-gejala yang dialami penderita penyakit bronchitis hampir mirip dengan penderita asma maupun tubercolosis. Selanjutnya berdasarkan hasil training pada 49 data sampai 10 epoch diperoleh bahwa tingkat keberhasilan jaringan LVQ untuk dapat mengenali pola dengan benar sebesar 95,92\%.

\subsection{Perbandingan Hasil Uji Coba}

Berikut ini disajikan tabel hasil uji coba dengan menggunakan beberapa parameter untuk mendapatkan variasi keakuratan pengujian sehingga dapat dilihat parameter terbaik.

Tabel 3 Perbandingan Hasil Uji Coba

\begin{tabular}{|c|c|c|c|c|}
\hline Uji ke- & $\boldsymbol{\alpha}$ & $\boldsymbol{D e c} \boldsymbol{\alpha}$ & Epoch & Keakuratan \\
\hline 1 & 0,3 & 0,00001 & 10 & $55,10 \%$ \\
\hline 2 & 0,3 & 0,001 & 10 & $63,27 \%$ \\
\hline 3 & 0,3 & 0,01 & 10 & $73,47 \%$ \\
\hline 4 & 0,2 & 0,00001 & 10 & $75,51 \%$ \\
\hline 5 & 0,2 & 0,0001 & 10 & $75,51 \%$ \\
\hline 6 & 0,2 & 0,01 & 10 & $77,51 \%$ \\
\hline 7 & 0,1 & 0,00001 & 10 & $95.92 \%$ \\
\hline 8 & 0,1 & 0,001 & 10 & $93,88 \%$ \\
\hline 9 & 0,1 & 0,1 & 10 & $89,90 \%$ \\
\hline 10 & 0,09 & 0,00001 & 10 & $91,84 \%$ \\
\hline 11 & 0,08 & 0,00001 & 10 & $89,90 \%$ \\
\hline 12 & 0,07 & 0,00001 & 10 & $87,76 \%$ \\
\hline 13 & 0,06 & 0,00001 & 10 & $91,84 \%$ \\
\hline 14 & 0,05 & 0,00001 & 10 & $85,71 \%$ \\
\hline
\end{tabular}

Berdasarkan hasil uji coba seperti yang disajikan pada Tabel 3 di atas terlihat bahwa tingkat keakuratan hasil diagnosa sangat dipengaruhi oleh pemilihan parameter laju pelatihan $(\alpha)$ dan penurunan laju pelatihan $(\operatorname{Dec} \alpha)$. Selain itu, berdasarkan pada proses pelatihan dan pengujian data diketahui juga bahwa pemilihan bobot awal juga sangatlah mempengaruhi tingkat keakuratan hasil diagnosa sehingga pemilihan bobot awal harus diambil dari data yang sudah ada. Dari hasil uji coba pada data testing diperoleh bahwa hasil pengujian terbaik 
adalah 95,92\%, berada pada nilai laju pelatihan $(\alpha)=0,1$ untuk penurunan nilai alfa $(\operatorname{Dec} \alpha)=$ 0,00001 dan epoch 10 .

\subsection{Form Diagnosa}

Untuk mendiagnosa penyakit saluran pernapasan dalam penelitian ini telah dirancang suatu program khusus yang dibangun dengan menggunakan toolbox yang telah disediakan MATLAB sehingga prosesnya menjadi mudah yaitu dengan menggunakan Graphical User Interface Design (GUIDe). Berikut ini desain tampilan antarmuka (interface) form diagnosa yang dirancang.

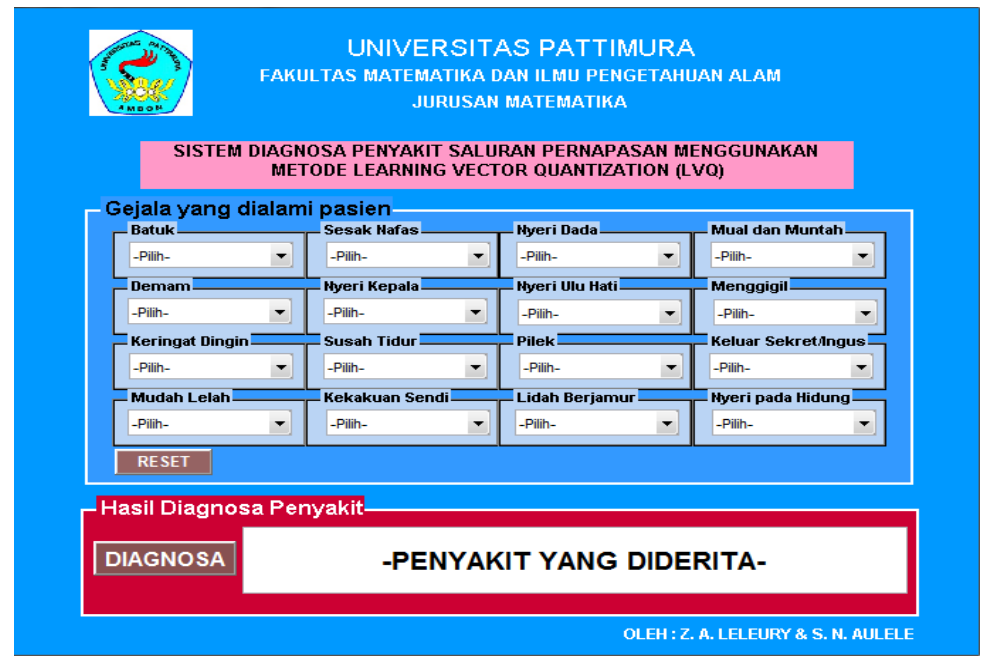

Gambar 3. Tampilan Interface Form Diagnosa

Tabel berikut ini adalah keterangan dari fungsi-fungsi tombol yang terdapat pada tampilan utama aplikasi.

Tabel 4. Fungsi Tombol Aplikasi

\begin{tabular}{|l|l|}
\hline \multicolumn{1}{|c|}{ Tombol } & \multicolumn{1}{|c|}{ Fungsi } \\
\hline Reset & $\begin{array}{l}\text { Tombol ini untuk mengatur ulang form utama aplikasi sehingga } \\
\text { form dapat diisi dengan data baru }\end{array}$ \\
\hline Diagnosa & $\begin{array}{l}\text { Tombol ini berfungsi untuk mendiagnosa penyakit dan } \\
\text { menampilkan nama penyakit dengan membaca hasil masukan dari } \\
\mathrm{X}_{1} \text { sampai } \mathrm{X}_{16} \text { dimana pola masukan ini didapat dari pengisian } \\
\text { gejala penyakit yang dilakukan oleh pasien }\end{array}$ \\
\hline $\begin{array}{l}\text { Gejala yang } \\
\text { dialami pasien }\end{array}$ & $\begin{array}{l}\text { Pada bagian ini ada 16 tombol yang merupakan gejala penyakit } \\
\text { yang harus diisi pasien }\end{array}$ \\
\hline
\end{tabular}

Berdasarkan data pemeriksaan pasien dengan menggunakan gejala-gejala yang dialami berikut adalah contoh penggunaan aplikasi pada salah satu pasien. Setelah memasukan gejalagejala yang dialami pasien berdasarkan data yang diperoleh selanjutnya klik tombol DIAGNOSA pada aplikasi maka akan diketahui nama penyakit yang dialami pasien sebagai berikut. 


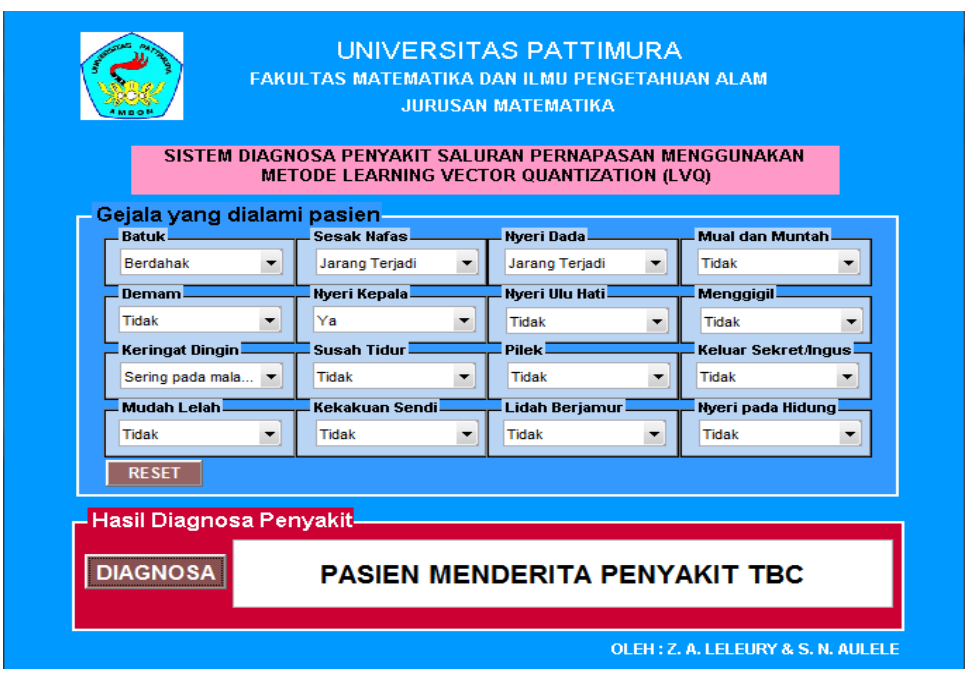

Gambar 4. Hasil Diagnosa Pasien

Aplikasi mendiagnosa pasien menderita penyakit Tuberculosis. Ternyata hasil diagnosa aplikasi ini sama dengan data yang dimiliki (hasil diagnosa dokter). Selanjutnya Proses yang sama dilakukan pada pasien-pasien yang lain, sehingga aplikasi ini dapat digunakan untuk memprediksi penyakit saluran pernapasan.

\section{Simpulan}

Berdasarkan penelitian maka dapat disimpulkan bahwa sistem yang dibuat mampu untuk mendiagnosa penyakit saluran pernapasan secara optimal dengan laju pelatihan $(\alpha)=0,1$ dan reduksi laju pelatihan $(\operatorname{Dec} \alpha)=0,00001$ serta diperoleh tingkat keberhasilan pengujian pelatihan sebesar $95,92 \%$.

\section{Daftar Pustaka}

1. Chou, H. C., Cheng, C. H., and Chang, J. R., 2007, Extracting drug utilization knowledge using self-organizing map and rough set theory, Expert Systems with Applications, 33(2), 499-508.

2. Fausett, L., 1994, Fundamentals Of Neural Network: Architectures, Fundamentals, and Aplications, Prentice-Hall, Inc., New Jersey.

3. Gil, D., Johnsson, M., Chamizo, J. M. G., Soriano, P. A., and Ruiz, F. D., 2009, Application of artificial neural networks in the diagnosis of urological dysfunctions, Expert Systems with Applications, 36(3), 5754-5760.

4. Temurtas, F., 2007, A comparative study on thyroid disease diagnosis using neural networks, Expert Systems with Applications, 36(1), 944-949. 
Zeth Arthur Leleury \& Salmon Notje Aulele / JMI Vol. 12 No. 1, April 2016 pp. 1- 10 